\title{
Maciej Michalski
}

\section{Współczesne użycia dyskursu filozoficznego i literatury}

\section{Contemporary Usage of Philosophical Discourse and Literature}

Nadszedt czas, aby odzwyczajono się przeceniać filozofię $i$ zbyt wiele od niej wymagać. $W$ dzisiejszej biedzie świata trzeba mniej filozofii, a więcej dbałości o myślenie, mniej literatury, a więcej dbałości o literę.

Martin Heidegger, List o humanizmie ${ }^{1}$

\section{Abstrakt}

W artykule omówiono trzy różne współczesne sposoby użycia filozofii i literatury w tekstach niefilozoficznych i nieliteraturoznawczych. Najczęściej oba dyskursy wykorzystuje się narzędziowo, przywołując je instrumentalnie (na przykład za sprawą cytatu) między innymi w piśmiennictwie popularyzatorskim czy dydaktyce. Filozofia i literatura mogą też zostać potraktowane jako źródło - punkt wyjścia refleksji poza macierzystym obszarem

1 Martin Heidegger, List o humanizmie (1946), tłum. Józef Tischner, w idem, Znaki drogi, (Warszawa: Fundacja Aletheia, 1995), 168. 
(na przykład w teorii literatury), a nawet przyczyna różnych procesów społecznych i politycznych (jak ma to miejsce w Drogach do niewolności Timothy'ego Snydera i Wojnach nowoczesnych plemion Michała Pawła Markowskiego). Najbardziej interesującym użyciem obu dyskursów jest odniesienie się do nich jako do symptomu - znaku czasu pozwalającego na stawianie diagnoz dotyczących współczesności (tak dzieje się między innymi w Po roku 1945. Latencja jako źródło współczesności Hansa Ulricha Gumbrechta czy Rysach na tafli. Teoria w polu psychoanalitycznym Andrzeja Ledera, a w wypadku literatury u Agaty Sikory w Wolności, równości, przemocy oraz esejach Zygmunta Baumana i Przemysława Czaplińskiego). Te sposoby wykorzystania obu dyskursów pokazują podobieństwa literatury i filozofii w wymiarze wyłącznie pragmatycznym, ale zarazem istotnym dla ich współczesnego funkcjonowania w sferze pozaspecjalistycznej. Zbieżność w tym zakresie jest świadectwem przemian pozycji obu dyskursów we współczesnej humanistyce polegających na utracie przez nie uprzywilejowanej (choć coraz bardziej marginalnej) pozycji. Zarazem literatura i filozofia w tej kryzysowej dla nich sytuacji zyskują nowe obszary oddziaływania w dyskursie publicznym, realizując swój poznawczy i refleksyjny potencjał za pomocą użytkowego ich wykorzystania.

Słowa klucze: literatura, filozofia, użycie, narzędzie, źródło, symptom

\begin{abstract}
This paper discusses three different contemporary uses of philosophy and literature in non-philosophical and non-literary texts. Most often, both discourses are used as tools, and they are invoked instrumentally (for example, by means of quotation) in popularizing literature or in teaching. Philosophy and literature can also be treated as a source or starting point for reflection outside its mother field (for example, in literary theory), or even as a cause of various social and political processes (as in Timothy Snyder's The Road to Unfreedom and Michał Pawet Markowski's Wojny nowoczesnych plemion [The Wars of Modern Tribes]). The most interesting usage of both discourses is to refer to them as the symptoms or signs of the times allowing us to make diagnoses about the present (this is the case, among others, in After 1945: Latency as Origin of the Present by Hans Ulrich Gumbrecht, in Rysy na tafli. Teoria w polu psychoanalitycznym [Cracks on the Surface. A Theory in the Psychoanalytic Field] by Andrzej Leder, while in relation to literature, in Agata Sikora's Wolność, równość, przemoc [Liberty, Equality, Violence], the essays by Zygmunt Bauman and Przemystaw Czapliński). These uses of the two discourses show the similarities between literature and philosophy on a purely pragmatic level that is relevant to their contemporary functioning in a non-specialist sphere. The convergence in this regard is a testimony to the transformation
\end{abstract}


of the position of both discourses in the contemporary humanities involving the loss of their privileged (though increasingly marginal) position. At the same time, literature and philosophy in this crisis situation are gaining new areas of influence in public discourse, realizing their cognitive and reflexive potential through their utilitarian use.

Keywords: literature, philosopy, usage, tool, source, symptom

Od napisania tych słów minęło siedemdziesiąt pięć lat i choć dziś znaczenia i pozycji filozofii - nawet w gronie filozofów - raczej się nie przecenia, wciąż wydają się aktualne, przede wszystkim ze względu na potrzebę „dbałości o myślenie”. Tę wypowiedź Martina Heideggera można rozumieć jako pewną krytykę filozofii i literatury, które oddaliły się od swoich źródeł i powinności, być może ze względu na ich petryfikację i instytucjonalizację oraz oderwanie od rzeczywistości, ale także ze względu na „biedę świata”. Czego dziś oczekujemy i oczekiwać możemy od filozofii i literatury?

Tożsamość filozofii, także tekstowa, była i pozostaje problematyczna w większości jej odmian i obszarów. Ale to, co może być kłopotem dla samych filozofów, próbujących z(re)definiować swoją dyscyplinę ${ }^{2}$, stanowi jednocześnie o jej potencjale i atrakcyjności. Bowiem ogólny charakter refleksji filozoficznej oraz jej historia, jako fundatorki różnych dziedzin humanistyki, pozwalają na dużą „łączliwość” z innymi dyskursami. Rzecz jasna ten jej status nie zawsze znajduje potwierdzenie w powszechnym odbiorze (przykładem jest uzus językowy, w którym określenie „filozofowanie” czy zwrot „nie filozofuj” nacechowane są negatywnie). Ale wspomniane powyżej cechy filozofii sprawiają, że wciąż chętnie bywa ona wykorzystywana w dość szerokim spektrum zastosowań - od czysto ornamentacyjnej roli przez ważny element kultury, równoprawny wobec jej innych rejestrów, po źródłowy i inspirujący charakter refleksji filozoficznej, która tym samym staje się (współ)odpowiedzialna za istotne procesy kulturowe i polityczne.

Podobnie ambiwalentny los dzieli z filozofią literatura, choć oczywiście ze względu na artystyczny charakter, wyraźne zróżnicowanie jej rejestrów i wynikającego z tego zakresu odbioru, sytuacja jest nieco inna.

2 Vide: Filozofia 2.0. Diagnozy i strategie, red. Maciej Soin, Przemysław Parszutowicz, (Warszawa: Wydawnictwo IFiS PAN, 2016), 30. 
Mimo powszechnego do niej dystansu ${ }^{3}$ wydaje się wciąż potrzebna. Olga Tokarczuk, niejako wirtualnie odpowiadając Heideggerowi, zwróciła uwagę na groźbę „literalizmu” - tendencji do „ograniczającej myślenie dosłowności” grożącej powrotem „dogmatyzmu i fundamentalizmu”" Natomiast literatura niejednokrotnie podejmuje te nieostre i wieloaspektowe problemy i wydaje się mieć nieoceniony potencjał w pielęgnowaniu złożoności i wielowymiarowości świata, jest - jak pisze Tokarczuk - „krainą Metaksy” - światem "pomiędzy”, pielęgnującym nieoczywistości, wieloznaczności, obszarem „doświadczenia, który zawsze pozostaje niejasny i zamazany, trudny do zwerbalizowania, w którym jednak ciągle trwają procesy stawania się, fermentacji, buzowania"6.

Bliskość literatury i filozofii, nie tylko na poziomie tekstowym, co wielokrotnie rozważano także na obszarze polskiej humanistyki, widać we współczesnych sposobach użycia obu form pisarstwa. Przyjrzenie się temu pragmatycznemu wymiarowi może mieć interesujący walor diagnostyczny, dotyczący miejsca obu dyskursów we współczesnym świecie, a co za tym idzie, ich roli i potencjału. Takiego rozpoznania najlepiej dokonać z pozadyscyplinarnej perspektywy, nieuwikłanej w specjalistyczne dociekania i motywacje. Inaczej mówiąc, o miejscu i wadze filozofii trafniej można rozstrzygnąć, przyglądając się jej pozafilozoficznym użyciom, zaś literaturze - pozaliteraturoznawczym.

W niniejszym artykule chciałbym krótko omówić na wybranych przykładach trzy rodzaje pozafilozoficznych użyć filozofii oraz pozaliteraturoznawczych literatury: jako narzędzia, jako źródła i jako symptomu. Egzemplifikację czerpać będę przede wszystkim z obszarów szeroko rozumianej humanistyki. Jak się bowiem okazuje, związki literatury

3 Spośród czytelników literatury większość obcuje z jej popularną odmianą, nieliczni czytają twórczość wysokoartystyczną. Vide: Roman Chymkowski, Zofia Zasacka, Stan czytelnictwa w Polsce w 2020 roku (Warszawa: Biblioteka Narodowa, 2021).

4 Olga Tokarczuk, Czuły narrator (Kraków: Wydawnictwo Literackie, 2020), 182.

5 Ibidem, 176.

6 Jak słusznie jednak zauważył Roman Kuźniar w swojej polemice z noblistką, literalizmu też potrzebujemy, nie tylko $\mathrm{w}$ naukach ścisłych, ale $\mathrm{w}$ dyskursie publicznym. „Zawsze bowiem istnieje ryzyko wulgaryzacji koncepcji radośnie i uwodzicielsko kontestujących rozum i doświadczenie”. I „nie tylko literalizm ma prawo być prymitywny”, fikcje i narracje też takie mogą być (Roman Kuźniar, „Nie zgadzam się z Olgą Tokarczuk", Gazeta Wyborcza, https://wyborcza.pl/magazyn/7,124059,26829698,do-olgi-tokarczuk-zacieranie-granicy-miedzy-fikcja-a-refleksja.html?disableRedirects=true [dostęp: 27.02.2021]).

7 Termin „użycie” stosuję zgodnie z ujęciem Richarda Rorty’ego jako każde postępowanie z tekstem, wszystkie bowiem są użyciami. Richard Rorty, „Kariera pragmatysty”, w Umberto Eco et al., Interpretacja i nadinterpretacja, red. Stefan Collini, tłum. i oprac. Tomasz Bieroń, (Kraków: Znak, 1996), 92. 
i filozofii także i tu są wyraźne, a pozaspecjalistyczna perspektywa pozwala pokazać ważny aspekt tej bliskiej relacji.

\section{Narzędzie}

O „narzędziowym” - i bardzo tradycyjnym - wykorzystaniu filozofii mówić można w sytuacjach, kiedy filozoficzne koncepcje, dzieła czy sposoby myślenia stają się różnego rodzaju wsparciem (wehikułem, argumentem, ozdobnikiem) w tekstach o zasadniczo niefilozoficznym charakterze. Najprostszym „narzędziowym” czy instrumentalnym wykorzystaniem filozofii jest cytat właśnie, szczególnie taki, który staje się przedmiotem komentarza lub ilustracji fragmentu wywodu, choć nieraz takie odwołanie zdaje się mieć wyłącznie inkrustacyjny charakter. W wypadku literatury konkretne utwory również wykorzystywane są pod postacią cytatów jako forma ornamentu lub estetycznego wehikułu perswazji.

$\mathrm{Z}$ nieco ciekawszym użyciem filozofii mamy do czynienia w tekstach, w których dyskurs filozoficzny dostarcza narzędzi właśnie do wypracowania określonych umiejętności lub kompetencji, np. nauki myślenia lub dyskutowania (por. Myślenie. Podręcznik użytkownika Bartosza Brożka); taki cel uzasadnia najczęściej obecność filozofii w programach studiów.

Podobnie „używa się" literatury w szkole jako narzędzia wychowawczego, budującego tożsamość narodową, kształtującego wyobraźnię, rozwijającego zasób słownictwa itp. ${ }^{8}$. Ta „edukacja literaturą" wyraźnie instrumentalizuje pisarstwo artystyczne i jest prawdopodobnie znacznie mniej skuteczna niż edukacyjne wykorzystanie filozofii jako nauki poprawnego myślenia.

Warto wspomnieć też o pewnym wykorzystaniu filozofii, a także literatury, które może stanowić odmianę narzędziowego ich użycia. Chodzi o terapeutyczne zastosowania filozofii i literatury. Ta pierwsza, szczególnie $\mathrm{w}$ jej stoickiej wersji, pojawia się $\mathrm{w}$ różnych poradnikach dobrego życia, np. Wyzwanie stoika Williama B. Irvine’a, Sztuka życia wedtug stoików Piotra Stankiewicza, Uwolnij się! Dobre życie według siedmiu filozofów-terapeutów oraz Stoicyzm uliczny. Jak oswajać trudne sytuacje Marcina Fabjańskiego. Warto dodać, że jest to zgodne ze starożytnym

8 Na tę instrumentalizację literatury zwracał uwagę Janusz Sławiński w 1977 roku, dodając, że ze względu na wieloznaczność i problemowość dzieł literackich „ze swojej natury niejako nie przylegają więc do poczciwie szkolnych treści wychowawczych" (Janusz Sławiński, „Literatura w szkole: dziś i jutro”, w idem, Teksty i teksty, red. Włodzimierz Bolecki, (Kraków: Universitas, 2000), 97. 
pojmowaniem filozofii - szczególnie przez stoików właśnie - jako „ćwiczenia duchowego"9. W wypadku literatury zaś biblioterapia jest uznaną formą terapeutyczną stosowaną przez pedagogów i psychologów dziecięcych; funkcjonuje w niej również ścieżka filozoficzna ${ }^{10}$.

Narzędziowe wykorzystanie może sugerować pełną instrumentalizację tego, co staje się narzędziem, jednak pozwala na znacznie więcej. Jak pisał Heidegger:

Wbijanie gwoździ nie tylko ma wiedzę o narzędziowym charakterze młotka, ale przyswoiło sobie to narzędzie najlepiej, jak tylko można. [...] im mniej się przyglądamy młotkowi-rzeczy, im sprawniej go używamy, tym bardziej źródłowy staje się stosunek do niego, tym bardziej bez osłony spotykamy ów młotek jako to, czym jest, jako narzędzie. Wbijanie gwoździ samo odkrywa specyficzną „dogodność" młotka ${ }^{11}$.

Być może więc narzędziowe użycie filozofii i literatury jest najważniejsze, ujawnia „dogodność” obu dyskursów, ich potencjał mimo pewnej ich instrumentalizacji. Warto mieć na względzie, że obie dziedziny niemal od początku traktowane były właśnie w taki sposób: filozofia jako „ćwiczenie duchowe”, jako element sztuki retorycznej, literatura jako medium religijne i filozoficzne, ale też forma ludyczna.

\section{Źródło}

Filozofia chętnie bywa prezentowana jako źródło refleksji, szczególnie w tych obszarach nauk społecznych i humanistycznych, które bliskie są dyskursowi filozoficznemu ze względu na alianse tematyczne czy też poprzez teoretyczny charakter rozważań. To częste zjawisko na terenie np. teorii literatury, dla której filozofia stanowi naturalnego sojusznika i wsparcie pozwalające naświetlać zjawiska tekstowe, szczególnie bliskie tematycznie refleksji filozoficznej (jak np. ontologia literatury, kwestia podmiotowości, statusu fikcji i referencyjności tekstów). Interesującym przykładem może być książka Andrzeja Zawadzkiego Obraz $i$ ślad, której autor wychodząc od teologicznych i filozoficznych refleksji

9 Vide: Pierre Hadot, Filozofia jako ćwiczenie duchowe, tłum. i oprac. Piotr Domański, (Warszawa: IFiS PAN, 1992).

10 Vide: Biblioterapia w praktyce. Poradnik dla nauczycieli, wychowawców i terapeutów, red. Ewelina J. Konieczna, (Kraków: Oficyna Wydawnicza „Impuls”, 2006), 16.

11 Martin Heidegger, Bycie i czas, tłum. i oprac. Bogdan Baran, (Warszawa: PWN 1994), 98. 
nad postawami wobec ikonosfery (idolatrią, ikonoklazmem i ikonofilią), dochodzi do interesującej koncepcji literackiej poetyki śladu.

Ale ten inspiracyjny potencjał filozofii bywa ujmowany szerzej i czasem uznaje się ją za „źródłowo” odpowiedzialną za kształt rzeczywistości, a przynajmniej wybranych jej obszarów. Tak postrzegana jest jej rola w Drodze do niewolności Timothy'ego Snydera oraz Wojnach nowoczesnych plemion Michała Pawła Markowskiego.

„Dopiero w połowie dziewiętnastego wieku mieszkańcy wielu krajów europejskich zyskali, w sposób na ogół przykry, świadomość, że zawiłe i zbyt trudne dla przeciętnego śmiertelnika książki filozoficzne mają wpływ całkiem bezpośredni na ich losy"12. Te słowa przywołuje w swojej rozprawie Snyder, uzasadniając niejako konieczność szukania źródeł dla narastających w drugiej dekadzie XXI wieku tendencji totalitarnych. Snyder w swojej rozprawie analizuje aktualną (od 2010 roku) sytuację Rosji (a następnie Europy i USA), przede wszystkim jej relacje z zachodnimi sąsiadami, wywodząc działania obecnych włodarzy Kremla $\mathrm{z}$ Władimirem Putinem na czele od refleksji Iwana Iljina, rosyjskiego filozofa i historyka zmarłego w 1954 roku. Taką rolę filozofii odzwierciedla też kompozycja rozprawy: Snyder, na początku wskazawszy na ważność refleksji Iljina, referuje jego poglądy, a następnie w kolejnych rozdziałach przywołuje istotne zdarzenia $\mathrm{z}$ drugiej dekady XXI wieku, traktując je jako istotne momenty „drogi do niewolności”. Wywód amerykańskiego historyka odzwierciedla zatem porządek chronologiczny i argumentacyjny: od źródła do wpływów i konsekwencji.

Rozważania Snydera skłaniają do pytań o odpowiedzialność filozofii i filozofów za działania polityków, a szerzej: za kształt rzeczywistości i biegu dziejów. W tej perspektywie refleksja filozoficzna jest performatywną i niemal interwencyjną aktywnością - i tak było co najmniej od połowy XIX wieku, jak twierdzi Czesław Miłosz. Ale jest też i odwrotnie: bez historii i oglądu rzeczywistości nie sposób pojąć kluczowych dla każdego z nas kwestii: „Jeśli chcemy się dowiedzieć więcej o dobru i złu, musimy wskrzesić historię"13.

Interwencyjny charakter mają bez wątpienia Wojny nowoczesnych plemion Markowskiego, które stanowią interesujący przykład łączenia różnych obszarów refleksji pomocnych w diagnozowaniu współczesności. Markowski, opierając się głównie na filozofii, szuka źródeł i rozwiązań współczesnych sporów, wcielając w życie model

12 Czesław Miłosz, Zniewolony umysł (Kraków: KAW, 1989), 19.

13 Timothy Snyder, Droga do niewolności. Rosja, Europa, Ameryka, tłum. i oprac. Bartłomiej Pietrzyk, (Kraków: Znak, 2019), 18. 
humanistyki zaangażowanej w pokojowe rozstrzygniecie aktualnych „wojen kulturowych”"14.

Markowski postępuje inaczej niż Snyder, który identyfikuje i opisuje filozoficzne źródła współczesnych zjawisk społeczno-politycznych w porządku chronologicznym - krakowsko-chicagowski literaturoznawca raczej porządkuje argumentacje i definiuje stanowiska, które stają się dla niego zarazem okazją do polemiki, a nawet oskarżenia. Filozofia stanowi dla niego bardzo istotny punkt odniesienia i wyjścia - autor swój projekt określa najkrócej jako polemikę z Marksowską jedenastą tezą o Feuerbachu („Filozofowie do tej pory jedynie interpretowali świat, idzie jednak o to, żeby go zmienić"15). A jednocześnie wyraża on niejednokrotnie dystans wobec filozofii jako takiej ${ }^{16} \mathrm{i}$ poszczególnych myślicieli (kilkakrotnie polemizuje np. z Hannah Arendt, Maxem Schelerem, Fryderykiem Nietzschem, a przede wszystkim z Georgiem Heglem). Nie zmienia to faktu, że to ona właśnie staje się odpowiedzialna za kształt współczesności - w tym sensie, że dostarczała argumentów, sankcjonowała, a tym samym inspirowała „wojny kulturowe”:

Otóż uważam, że bez tego dyskursu, zarówno Heglowskiego, jak i tego opartego na Heglu, wojny kulturowe nie mogłyby się pojawić na horyzoncie nowoczesności. To bowiem Hegel pokazał po raz pierwszy, że „inny” jest absolutnym warunkiem podmiotowości. [...] Podłożem nowoczesnych wojen kulturowych jest heglizm bez pojednania w duchu, nieustanna wojna pragnień, starcie wartości, nieustanna konfrontacja rzeczywistości, które walczą o swoje samouzasadnienie. Nie byłoby wojen kulturowych bez Hegla $[\ldots]^{17}$.

„Winny” jest także Jacques Derrida jako istotny poheglowski wpływowy piewca inności, a także Augustyn, który usankcjonował przekonanie, że prawdę można odkryć jedynie we wnętrzu samego siebie, co przyczyniło się do degradacji rozumienia prawdy i polityczności ${ }^{18}$.

Markowski płynnie przechodzi w swoich rozważaniach od filozofii do polityki i zjawisk społecznych, a także popkultury i własnych

14 W świetle jego dawnych deklaracji i sporów z wczesnych tekstów o Derridzie i pragmatyzmie przez Politykę wrażliwości po niedawną dyskusję w „Tekstach Drugich” (2014, nr 1) z Janem Sową - wydaje się to interesującym zwrotem.

15 Michał P. Markowski, Wojny nowoczesnych plemion. Spór o rzeczywistość w epoce populizmu (Kraków: Karakter, 2019), 22.

16 Np. ibidem, 76, 251.

17 Ibidem, 106, 109.

18 Ibidem, 71, 107. 
doświadczeń. Daje to dość spójny (może zbyt spójny?) i całościowy (czy nie zanadto kompletny?) obraz świata, w którym refleksja filozoficzna pełni istotne miejsce i do której warto się odwołać, aby zrozumieć rzeczywistość. Czasem autor przywołuje ją nieco „narzędziowo”, jako zbiór koncepcji i argumentów przydatnych w budowaniu własnego wywodu, tak np. „wykorzystuje” rozważania Nietzschego ${ }^{19}$. Ale też zbliża się czasem do „symptomatycznego" użycia filozofii.

We współczesnym dyskursie nauk humanistycznych i społecznych często w źródłowej roli występuje neoliberalizm - jako przyczyna różnych, zwykle negatywnie ocenianych zjawisk. I choć kojarzy się on głównie z ekonomią, ma swoje filozoficzne oblicze. Tak wyjaśnia zamysł swojej książki Język neoliberalizmu Tomasz Szymon Markiewka:

Moim celem jest pójście w przeciwną stronę niż ten ekonomizujący trend. Pragnę wprowadzić język filozofii w miejsce, które wydaje się domeną ekonomistów. Chcę pokazać, że wyzwania, przed którymi stoimy w związku $\mathrm{z}$ dominacją neoliberalizmu, nie dotyczą jedynie spraw takich jak polityka podatkowa czy prawa socjalne, ale są również powiązane z zagadnieniami filozoficznymi ${ }^{20}$.

I choć takie ujęcie sugeruje, że mamy do czynienia z wtórnym niejako „wprowadzeniem języka filozofii” do niefilozoficznego obszaru, autor w konkluzji jednak pokazuje źródłowość, a jednocześnie „przezroczystość” filozoficznych założeń w neoliberalnym myśleniu:

Teza tej książki jest skromniejsza, ale nie mniej doniosła: tak jak naiwnością byłoby kierowanie uwagi tylko na sferę filozoficzną, tak też naiwnością jest jej lekceważenie. Filozofia ma swoje konsekwencje. Tym bardziej filozofia, która staje się przezroczysta ${ }^{21}$.

Takie konsekwencje trudno wskazać w wypadku literatury. Znacznie trudniej potraktować ją jako dyskurs źródłowy, ale nie ze względu na jej nieprzydatność czy nieskuteczność w tym zakresie. Literatura, ze względu na walory estetyczne osłabiające tym samym zwykle niedyskursywny

19 Ibidem, 193 i nast. Warto dodać, że Markowski jest autorem monografii poświęconych J. Derridzie i F. Nietzschemu.

20 Tomasz Sz. Markiewka, Język neoliberalizmu. Filozofia, polityka i media (Toruń: Wydawnictwo Naukowe UMK, 2017), 22.

21 Ibidem, 257-258. 
i perswazyjny (a może nawet argumentacyjny?) charakter ${ }^{22}$, raczej eksploruje „krainę Metaksy” niż staje się wyraźnie udokumentowanym źródłem określonych postaw i działań. Nie można wykluczyć wpływu literatury - analogicznego do powyżej opisanego źródłowego oddziaływania filozofii - ale jest to znacznie słabiej „mierzalne” i utrwalane w świadectwach odbioru. Literatura natomiast spełnia się czasem w roli symptomatycznej.

\section{Symptom ${ }^{23}$}

Refleksja filozoficzna może stanowić też swoisty znak czasu i tak też bywa traktowana w refleksji humanistycznej. To ujęcie znane z obszaru historii idei i estetyki ${ }^{24}$. Warto również dodać, że współczesne zwroty w humanistyce, zwykle ekstensywnie interdyscyplinarne, chętnie eksploatują filozofię, przypisując jej istotną rolę jako tyleż refleksji źródłowej, co właśnie symptomu istotnych tendencji kulturowych.

Świetnymi przykładami takiego symptomatycznego i korespondencyjnego myślenia mogą być Po roku 1945 roku. Latencja jako źródto współczesności Hansa Ulricha Gumbrechta i Rysa na tafli. Teoria w polu psychoanalitycznym Andrzeja Ledera.

Ta pierwsza sama w sobie stanowi interesujące dzieło, utkane jest bowiem tyleż z refleksji - głównie filologicznej, historycznej i filozoficznej - co z istotnych wątków autobiograficznych, opisów przeżyć i subiektywnych spostrzeżeń samego autora. Gumbrecht w wielu miejscach swojej książki symptomatycznie traktuje pisarstwo filozoficzne Martina Heideggera, Alberta Camusa, Carla Schmitta, Jeana-Paula Sartre’a, a także Jeana-Françoisa Lyotarda - „symptomatologa teraźniejszości”25.

22 Vide: Andrzej Stoff, „Perswazyjna niemoc literatury”, w Rozgrywanie światów. Formy perswazji w kulturze współczesnej, red. Inga Iwasiów, Jerzy Madejski, (Szczecin: Wydawnictwo Naukowe Uniwersytetu Szczecińskiego, 1994).

23 Symptomy rozumiem tu zgodnie z potocznym znaczeniem jako oznaki jakiegoś zjawiska. Z braku miejsca nie rozwijam tu wątków - potencjalnie interesujących - związanych np. z Freudowskim rozumieniem symptomu lub Lacanowskim syntomem.

24 Dobrym tego przykładem - oprócz klasycznej pracy Arthura O. Lovejoya pt. Wielki łańcuch bytu - są rozważania Erwina Panofsky’ego, który pokazywał zbieżność scholastyki z rozwojem gotyku - oba nurty w różny sposób wyrażały tę samą wizję rzeczywistości (Erwin Panofsky, „Architektura gotycka i scholastyka”, w idem, Studia z historii sztuki (Warszawa: PIW, 1971).

25 Hans Ulrich Gumbrecht, Po roku 1945. Latencja jako źródło współczesności, tłum. Aleksandra Paszkowska, wstęp Adam Krzemiński, (Warszawa: Wydawnictwo Krytyki 
Heidegger - ewolucja jego postawy i poglądów - jest dla Gumbrechta szczególnie emblematyczny (autor używa zresztą tego określenia, 33) dla historii (nie tylko intelektualnej) Niemiec i ich powojennych losów. Powojenny List o "humanizmie" zostaje zestawiony z sytuacją ekonomiczną i społeczną tego kraju, zbieżność widać nawet w metaforyce - Heideggerowska „bieda świata” i „ubóstwo filozofii” korespondują z rzeczywistym niedostatkiem Niemców (33-36); podobne analogie pojawiają się przy omawianiu zagrożeń „wieku atomowego" (184 i nast.). Ten sam sposób postępowania Gumbrecht stosuje wobec Sartre’a i jego Bycia i nicości, także i tego filozofa traktując jako uważnego, choć pewnie nie zawsze samoświadomego, diagnostę swoich czasów (103 i nast.; 118 i nast.), oraz Alberta Camusa (83 i nast.).

Istotnym elementem budowania symptomatycznych analogii jest pokazywanie przez Gumbrechta podobieństw w diagnozie powojennej sytuacji - zbieżności między filozofią i sztuką. W wypadku Heideggera wskazuje na analogię z filmami (Paisą Roberto Rosselliniego, 76, czy Na wschód od Edenu, 88), poezją (Gottfrieda Benna, 81 i nast.), powieściami (Czasem milczenia Luisa Martína-Santosa, 86), dramatami (szczególne znaczenie dla wywodów Gumbrechta ma Czekając na Godota Samuela Becketta, 145 i nast.), a nawet piosenkami Edith Piaf (144). W podobny sposób i w tym samym kontekście omawiane są dzieła Sartre’a, Camusa, Arendt, Schmitta, których autor Po roku 1945 zestawia z Heideggerem i jego powojenną eseistyką.

Dla Gumbrechta bowiem cała sfera piśmiennictwa oraz doświadczeń kształtuje określone Stimmung - „wszechobecnej atmosfery, jak i subiektywnie przeżywanego nastroju" właściwe swoim czasom (53). Rzecz jasna nie są tu możliwe twarde dowody, „nie ma empirycznej metody na udowodnienie" tez autora, co sam przyznaje (254), łatwo zatem zarzucić autorowi zbytnią swobodę, a może nawet dezynwolturę w łączeniu różnych dyskursów, form wyrazu, zdarzeń i przeżyć - swoistą metodę, którą znamy z najbardziej znanego dzieła Gumbrechta, czyli W 1926 roku. Ale takie trans-, a może adyskursywne podejście - wyzwalające teksty z ram ich dyskursów, a zarazem mocno osadzające je w czasoprzestrzennym konkrecie - pozwala być może zobaczyć więcej i lepiej zrozumieć rzeczywistość. W ten sposób filozofia, pozbawiona swoich uniwersalistycznych roszczeń, zyskuje inny, diagnostyczny, symptomatyczny wymiar.

Podobnie książka Andrzeja Ledera jest analizą dwudziestowiecznych teorii, także filozoficznych, traktowanych wprost jako symptomów

Politycznej, 2015), 254. Kolejne odniesienia do tej książki sytuuję bezpośrednio w tekście głównym. 
traum czy - szerzej - trudnych doświadczeń XX wieku: „Atoli z naszej perspektywy to filozofia, jako wypowiedź, przynależy do dziejów owej postaci, którą jest XX stulecie. [...] Wyłonienie się traumy jako »teoretycznego przedmiotu « rozumiane jest jako złożony proces, dokonujący się w polu podmiotowym ${ }^{26}$. Wcześniej widoczne są raczej symptomatyczne formy wypowiedzi, formy języka filozoficznego, które tylko pośrednio wskazują na doświadczenie traumy [...] poszczególne konstrukcje teoretyczne mogą być traktowane jako mechanizmy obronne” (13); „Z punktu widzenia naszego zadania teorię filozoficzną badać trzeba jako symptom kryzysu, z którym podmiot europejski zmagał się po dramatycznym traumatycznym - doświadczeniu Wielkiej Wojny" (54). Najdobitniejszym symptomem traumy jest (paradoksalnie!) dążące do scjentystycznej precyzji filozofowanie Koła Wiedeńskiego, które dość agresywnym rygoryzmem próbowało przeciwdziałać oddalaniu się języka od rzeczywistości i rozpadowi korespondencyjnej koncepcji prawdy, obwiniając o to metafizykę i filozofię spekulatywną (56 i nast.) - to reakcja, którą w języku psychoanalizy lacanowskiej rozumieć należy tak: „Chodziło o usunięcie tych fragmentów dyskursu, które nasilały, wypowiadały wprost załamanie wiary w referencję, w odniesienie słów i rzeczy. [...] Aby osiągnąć te cele, podmiot [...] zanegował Innego, wielkie A, oznaczające nienaoczną sumę całego pola językowego, skupił się zaś na znaczacym, dopełniającym, uchwytnym" (56). Kolejnymi symptomami europejskich traum będą według Ledera fenomenologia (77 i nast.), powojenna filozofia francuska:

Straciwszy idealny obraz siebie, w jednym krótkim momencie przegapiwszy „statek historii, przepływający nieopodal pośród nocy”, francuski podmiot znalazł się wobec czegoś zupełnie zwykłego, tak zwykłego, że wręcz tracącego kształt i istnienie. Nie mógł znieść tej utraty i być może dlatego musiał rozwijać symptomy, pseudorewolucyjną złą wi iąę, a potem melancholię dekonstrukcji, symptomy kształtujące kulturę intelektualną sporej części świata przez następne dziesiątki lat (197).

Także „symptomem było powojenne milczenie na temat Zagłady” (218, również cały rozdział Eichmann jak objaw)...

Leder, w podobny sposób jak w Prześnionej rewolucji, aplikuje psychoanalityczne ujęcie do zbiorowości lub nawet nieosobowych bytów (jak

26 Andrzej Leder, Rysa na tafli. Teoria w polu psychoanalitycznym (Warszawa: PWN, 2016), 11. Kolejne odniesienia do tej książki sytuuję bezpośrednio w tekście głównym. Wszelkie wyróżnienia - kursywa i rozstrzelony druk - w cytatach pochodzą od A. Ledera. 
wiek), uzyskując dzięki temu syntetyczny obraz przemian myślenia teoretycznego stanowiącego symptom, reakcję na dwudziestowieczne traumy. $\mathrm{Z}$ tej perspektywy filozofia okazuje się równie wrażliwa na rzeczywistość - kontekstualna, nieuniwersalna, afektywna - tak jak człowiek, który uprawia ten dyskurs.

Symptomatyczne funkcjonowanie dyskursu filozoficznego w sposób dość istotny przedefiniowuje go, a przynajmniej wyraźnie go sytuuje w nieco innej pozycji, niż to zwykle ma miejsce. Takie ujęcie filozofii dowodzi niejako performatywnego potencjału tego dyskursu - filozofowie ukształtowali być może naszą przeszłość i teraźniejszość, co najmniej zaś - być może retroaktywnie - historia przeczytana została inaczej i inaczej zrozumiana. A zarazem tak potraktowana filozofia pokazuje, że nie stanowi ona źródła refleksji czy podstawy dla innych obszarów humanistyki oraz odbiera jej uprzywilejowaną "metapozycję" i uniwersalistyczne roszczenia. Pokazuje jej, jakie w gruncie rzeczy zajmuje miejsce: jako mocno osadzonej w kontekście refleksji, która jest świadectwem swoich czasów, a zarazem często zacierającej swój nieuchronny prezentyzm. Jednocześnie zabieg taki sprawia, że zyskuje ona nowe pole oddziaływania. Dyskurs filozoficzny staje się w tej perspektywie przede wszystkim podstawą do stawiania diagnoz lub diagnozą wprost, ale też formą świadectwa ${ }^{27}$, reprezentacją doświadczenia ${ }^{28}$, co bynajmniej nie unieważnia jej poznawczych i/lub „mądrościowych” aspiracji. Wręcz przeciwnie: ukontekstowiona i ukonkretniona refleksja zyskuje na wartości, bo unikając abstrakcji, nie anihiluje rzeczywistości - jak zarzucał jej Nietzsche - i nie zapoznaje swoich doświadczeniowych źródeł oraz osadzenia w kontekście swoich czasów.

Doświadczeniowy wymiar filozofii wyraźnie zbliża ją do literatury, którą można zdefiniować i badać jako formę reprezentacji doświadczenia $^{29}$. I, podobnie jak filozofia, bywa używana poza specjalistycznym dyskursem jako symptom. Dzieje się tak w rozważaniach Przemysława Czaplińskiego - wprawdzie literaturoznawcy, ale od pewnego czasu częściej działającego na obszarze refleksji kulturoznawczej i socjologicznej.

27 Vide: Berel Lang, „»Ja sam uszedłem, by ci o tym donieść«, czyli filozoficzne dawanie świadectwa”, tłum. Anna Ziębińska-Witek, Teksty Drugie 3/117 (2009).

28 Vide: Maciej Michalski, Filozof jako pisarz. Kołakowski, Skarga, Tischner (Gdańsk: słowo/obraz terytoria, 2010), 85 i nast.

29 Vide: Literackie reprezentacje doświadczenia, red. Włodzimierz Bolecki, Ewa Nawrocka, (Warszawa: Instytut Badań Literackich PAN, 2007); Ryszard Nycz, Poetyka doświadczenia. Teoria - nowoczesność - literatura (Warszawa: Instytut Badań Literackich PAN, 2012) (szczególnie rozdział: Od teorii nowoczesnej do poetyki doświadczenia). 
W artykule Krańce wyobraźni symptomatyczne potraktowanie literatury uzasadnione jest następująco:

Materiał, który posłuży mi do sformułowania wniosków, czerpać będę z polskiej literatury ostatniego ćwierćwiecza. Na pytanie, jaką wartość ma analizowanie tekstów literackich w sytuacji, gdy kruszą się podstawy ogólnoświatowego ładu, odpowiem najprościej: jeśli mam rację, sądząc, że znaleźliśmy się na krańcach wyobraźni, to literatura jest równoprawnym względem innych dyskursów uczestnikiem debaty o rzeczywistości. Może nawet uczestnikiem zasługującym na chwilę uwagi, skoro właśnie on najsprawniej posługuje się wyobraźnią ${ }^{30}$.

Podobne podejście stosuje Czapliński w swojej książce pt. Poruszona mapa. O wyobraźni geograficzno-kulturowej polskiej literatury przełomu $X X i$ XXI wieku, traktującej o zmianie polskiego geograficznego imaginarium, którego symptomatycznym świadectwem są utwory literackie, a co więcej: na tę zmianę wpływają, kwestionując oczywistości i wciągając czytelników „w doświadczenie kryzysu orientacji”31.

Literatura staje się szczególnie wartościowym diagnostycznie symptomem przemian obyczajowych i postaw - można powiedzieć: na obszarze „krainy Metaksy”. Tak traktuje ją Agata Sikora w swojej interesującej i unikającej jednoznacznych ocen refleksji nad współczesnymi wojnami kulturowymi i polityką tożsamości. Autorka, analizując powieść Ignacego Karpowicza ości pisze:

Niestandardowe, improwizowane więzi miłosno-przyjacielsko-rodzicielskie rozsadzają przestrzeń ustabilizowanych tożsamości i nuklearnych rodzin. Ich podstawą są nie idee, ale konkretne, nieustannie negocjowane relacje międzyludzkie, fundamentem - współpraca i lojalność ponad granicami światopoglądów. Powieść Ignacego Karpowicza ości problematyzuje sprzeczność, która w progresywnych utopiach pozostaje zazwyczaj w cieniu: bycie absolutnie szczerym wywołuje cierpienie, wcale nie tak łatwe do ukojenia. Karpowicz rzuca wyzwanie zarówno patriarchalnemu porządkowi, jak i hasłu „prawda nas wyzwoli” (wspólnego chrześcijanom i zwolennikom polityki tożsamości) [...]. Powieść jest wyraźnie polemiczna wobec polityki tożsamości - więź i możliwość komunikacji ponad

30 Przemysław Czapliński, „Krańce wyobraźni”, w Prognozowanie teraźniejszości: myślenie z wnętrza kryzysu, red. Przemysław Czapliński, Joanna B. Bednarek, (Gdańsk: Katedra, 2018), 62.

31 Przemysław Czapliński, Poruszona mapa. Wyobraźnia geograficzno-kulturowa polskiej literatury przełomu XX i XXI wieku (Kraków: Wydawnictwo Literackie, 2016), 8. 
różnicami są tu znacznie ważniejsze niż prawo do pełnej autoekspresji; „ości”, takie jak miłość czy solidarność, ważniejsze niż tożsamośćc ${ }^{32}$.

Tym samym utwór literacki nie tylko stanowi symptom zjawisk współczesnej kultury, ale jednocześnie staje się propozycją, wyzwaniem, jak wobec nich się usytuować. Taką drogą - pomiędzy radykalnymi rozwiązaniami i biegunami konfliktu - idą również refleksje autorki.

Interesującym przykładem symptomatycznego użycia literatury, pokazującego jej przewagę wobec innych dyskursów, jest też jeden $\mathrm{z}$ artykułów Zygmunta Baumana z 44 listów ze świata płynnej nowoczesności, w którym teksty Italo Calvino potraktował jako równoważny, a nawet bardziej wartościowy głos w dyskusji o współczesnym świecie. Jak pisał socjolog, utwór włoskiego prozaika:

jest znacznie bardziej przenikliwym i przejmującym raportem z naszego dziwnego świata płynnej nowoczesności niż listy, które sam wysyłam; opowiedziana w nim historia skomponowana zaś została z niedościgłą dla mnie siłą wyobraźni, talentem literackim i artystyczną urodą ${ }^{33}$.

I tak symptomatyczna refleksja łączy się z „,artystyczną urodą”, a rozważania socjologiczno-filozoficzne Baumana pokazują jednocześnie odrębne potencjały dyskursywności i literackości, a zarazem ich wzajemną bliskość.

Narzędziowe, źródłowe czy symptomatyczne traktowanie filozoficznych rozważań i literackich tekstów prawdopodobnie nie wyczerpuje katalogu współczesnych form ich obecności w dyskursie publicznym, nie są to też taktyki zupełnie nowe. Warto jednak zwrócić uwagę na współczesny kontekst i (być może) konsekwencje przedstawionych tu tendencji.

Po pierwsze, powyżej omówione teksty wydają mi się oznaką - być może nie zanadto wyrazistą - nieco innej obecności filozofii w dyskursie nauk humanistycznych i społecznych. Nie jest ona ani nadrzędnym metadyskursem, ani autonomiczną, choć niszową dyscypliną akademicką. W najciekawszej, jak sądzę, omówionej powyżej odmianie swojej

32 Agata Sikora, Wolność, równość, przemoc. Czego nie chcemy sobie powiedzieć (Kraków: Karakter, 2019), 50-53.

33 Zygmunt Bauman, „Plemiona i nieboskłony”, w idem, 44 listy ze świata płynnej nowoczesności, tłum. i oprac. Tomasz Kunz, (Kraków: Wydawnictwo Literackie, 2011), 259. 
obecności - jako symptomu - jest ona traktowana jako równoprawna część kultury i dyskursu publicznego, inspirująca zwroty współczesnej humanistyki, jednocześnie bez nakładania na nią zobowiązań jako królowej nauk czy - przeciwnie - formy zaangażowania społeczno-politycznego.

Ta zmiana dotyczy też po części literatury, która wychodzi poza swoje zwyczajowe narzędziowe „użycia” lub ludyczne przeznaczenia i traktowana bywa coraz śmielej jako symptom zjawisk kulturowych. To również wydaje się wartościową formą publicznej obecności literatury, szerzej odsłaniającej jej słabo dostrzegany potencjał.

Po drugie filozofia, podobnie jak i istotne obszary dyskursu współczesnej humanistyki, znalazła się w sytuacji poszukiwania nowych form tekstowej obecności. Ten genologiczny kryzys trwa ponad dwa wieki ${ }^{34}$, z czasem jednak nasilił się ze względu na zmieniające się okoliczności wpływające m.in. na status humanistyki i funkcjonowanie pisma. Dzięki różnym użyciom filozofii zyskuje pod tym względem zarówno ona, jak i „pasożytujące” na niej wypowiedzi, nawet jeśli skutkuje to „zmąceniem” dyskursów ${ }^{35}$. I to samo można powiedzieć o literaturze, która - tracąc być może autonomię wynikającą z estetycznych uwarunkowań - staje się wyraźniej obecna i szerzej pokazuje swój poznawczy i refleksyjny potencjał.

Tym samy filozofia i literatura ponownie spotykają się razem, dzieląc podobny los - w „czasie marnym” $\mathrm{i}$ „biedzie świata”.

\section{Bibliografia}

Bauman Zygmunt, „Plemiona i nieboskłony”, w Zygmunt Bauman, 44 listy ze świata plynnej nowoczesności, tłum. i oprac. Tomasz Kunz, (Kraków: Wydawnictwo Literackie, 2011).

Biblioterapia w praktyce. Poradnik dla nauczycieli, wychowawców i terapeutów, red. Ewelina J. Konieczna, (Kraków: Oficyna Wydawnicza „Impuls”, 2006). Chymkowski Roman, Zasacka Zofia, Stan czytelnictwa w Polsce w 2020 roku (Warszawa: Biblioteka Narodowa, 2021).

Czapliński Przemysław, Krańce wyobraźni, w Prognozowanie teraźniejszości: myślenie z wnętrza kryzysu, red. Przemysław Czapliński, Joanna B. Bednarek, (Gdańsk: Katedra, 2018).

34 Vide: Julián Marias, „Gatunki literackie w filozofii”, tłum. i oprac. Alberta Labuda, Pamiętnik Literacki 70/2 (1979).

35 Wykorzystuję tu metaforę Clifforda Geertza, „O gatunkach zmąconych. (Nowe konfiguracje myśli społecznej)", tłum. i oprac. Zdzisław Łapiński, w Postmodernizm. Antologia przekładów, wybór i oprac. Ryszard Nycz, (Kraków: Wydawnictwo Baran i Suszczyński, 1997). 
Czapliński Przemysław, Poruszona mapa. Wyobraźnia geograficzno-kulturowa polskiej literatury przełomu XX i XXI wieku (Kraków: Wydawnictwo Literackie, 2016).

Filozofia 2.0. Diagnozy i strategie, red. Maciej Soin, Przemysław Parszutowicz, (Warszawa: Wydawnictwo IFiS PAN, 2016).

Geertz Clifford, „O gatunkach zmąconych. (Nowe konfiguracje myśli społecznej)”, tłum. i oprac. Zdzisław Łapiński, w Postmodernizm. Antologia przekładów, wybór i oprac. Ryszard Nycz, (Kraków: Wydawnictwo Baran i Suszczyński, 1997).

Gumbrecht Hans Ulrich, Po roku 1945. Latencja jako źródło współczesności, tłum. Aleksandra Paszkowska, wstęp Adam Krzemiński, (Warszawa: Wydawnictwo Krytyki Politycznej, 2015).

Hadot Pierre, Filozofia jako ćwiczenie duchowe, tłum. i oprac. Piotr Domański, (Warszawa: Wydawnictwo IFiS PAN, 1992).

Heidegger Martin, „List o »humanizmie«” (1946), tłum. Józef Tischner, w idem, Znaki drogi (Warszawa: Fundacja Aletheia, 1995).

Kuźniar Roman, „Nie zgadzam się z Olgą Tokarczuk”, Gazeta Wyborcza https:// wyborcza.pl/magazyn/7,124059,26829698,do-olgi-tokarczuk-zacieranie-granicy-miedzy-fikcja-a-refleksja.html?disableRedirects=true (dostęp: 27.02.2021).

Lang Berel, „»Ja sam uszedłem, by ci o tym donieść«, czyli filozoficzne dawanie świadectwa”, tłum. Anna Ziębińska-Witek, Teksty Drugie 3/117 (2009): 163-175.

Leder Andrzej, Rysa na tafli. Teoria w polu psychoanalitycznym (Warszawa: Wydawnictwo Naukowe PWN, 2016).

Literackie reprezentacje doświadczenia, red. Włodzimierz Bolecki, Ewa Nawrocka, (Warszawa: Instytut Badań Literackich PAN, 2007).

Marias Julián, „Gatunki literackie w filozofii”, tłum. i oprac. Alberta Labuda, Pamiętnik Literacki 70/2 (1979): 309-320.

Markiewka Tomasz Szymon, Język neoliberalizmu. Filozofia, polityka i media (Toruń: Wydawnictwo Naukowe UMK, 2017).

Markowski Michał Paweł, Wojny nowoczesnych plemion Spór o rzeczywistość w epoce populizmu (Kraków: Karakter, 2019).

Michalski Maciej, Filozof jako pisarz. Kołakowski, Skarga, Tischner (Gdańsk: słowo/obraz terytoria, 2010).

Miłosz Czesław, Zniewolony umysł (Kraków: KAW, 1989).

Nycz Ryszard, Poetyka doświadczenia. Teoria - nowoczesność - literatura (Warszawa: Instytut Badań Literackich PAN, 2012).

Panofsky Erwin, Architektura gotycka i scholastyka, w idem, Studia $z$ historii sztuki, (Warszawa: PIW, 1971).

Rorty Richard, Kariera pragmatysty, w Umberto Eco et al., Interpretacja i nadinterpretacja, red. Stefan Collini, tłum. i oprac. Tomasz Bieroń, (Kraków: Znak, 1996).

Sikora Agata, Wolność, równość, przemoc. Czego nie chcemy sobie powiedzieć (Kraków: Karakter, 2019). 
Sławiński Janusz, „Literatura w szkole: dziś i jutro”, w idem, Teksty i teksty (Kraków: Universitas, 2000).

Snyder Timothy, Droga do niewolności. Rosja, Europa, Ameryka, tłum. i oprac. Bartłomiej Pietrzyk, (Kraków: Znak, 2019).

Stoff Andrzej, „Perswazyjna niemoc literatury”, w Rozgrywanie światów. Formy perswazji w kulturze współczesnej, red. Inga Iwasiów, Jerzy Madejski, (Szczecin: Wydawnictwo Naukowe Uniwersytetu Szczecińskiego, 1994).

Tokarczuk Olga, Czuły narrator (Kraków: Wydawnictwo Literackie, 2020).

Zawadzki Andrzej, Obraz i ślad (Kraków: Wydawnictwo Uniwersytetu Jagiellońskiego, 2014). 